\title{
Using Etherpad for Online Collaborative Writing Activities and Learners with Different Language Learning Strategies
}

\author{
Erdal Ayan a 1 (D), S. Sadi Seferoğlu b (D) \\ ${ }^{a}$ Hacettepe University, Department of Computer Education and Instructional Technology, Ankara, 06800, Turkey \\ ${ }^{b}$ Hacettepe University, Department of Computer Education and Instructional Technology, Ankara, 06800, Turkey
}

Received 19 July 2017 | Received in revised form 28 September 2017 | Accepted 13 October 2017

\begin{abstract}
The current study is a research on use of EtherPad platform for online collaborative writing tasks. There are lots of reports and research dealing with these platforms, the integration of technology and its use for online educational purposes. Many of them showed that online education is very new for the learners and there is little contribution to their learning process in terms of changing their traditional educational behaviors. Furthermore, the teachers are still focusing on using technology for their own sake but there is very little attention on in-class or out-class activities since most of the time, their in-service training including appropriate technological tools, syllabus integration and consultation are disregarded. It seems that there's very little interest on synchronous collaborative online writing by the language learners with different language learning strategies. Therefore, this study investigates how the learners with different language learning strategies behave in online platforms while they are using online materials and particularly writing over EtherPad. Voluntary participants could easily integrate into online platforms and spent remarkable effort and time to cooperate and complete all given tasks and especially synchronous online collaborated writing tasks. As a result of the research, it was observed that performance of two groups of participants with different language learning strategies have significantly differentiated, which suggested that such online writing activities can be implemented to diagnose such differences among the learners and be useful to manipulate their learning process in order to assist them to improve their certain learning skills and motivate them according to their needs.
\end{abstract}

(C) 2017 EJAL \& the Authors. Published by Eurasian Journal of Applied Linguistics (EJAL). This is an open-access article distributed under the terms and conditions of the Creative Commons Attribution license (CC BY-NC-ND) (http://creativecommons.org/licenses/by-nc-nd/4.0/).

Keywords: online learning, synchronous learning, language learning strategies, online collaborative writing

\section{Introduction}

Use of online platforms for language teaching has enormously increased in today's English language teaching literature in accordance with technological advances in computerized educational methods and techniques. Personalized language teaching designed according to learner needs and existent language proficiency over online environments has also contributed to the field a lot. Lynch (2004), for instance, says

\footnotetext{
1 Erdal Ayan, Tel.: +90-312-7176

E-mail address: erdal.ayan@hacettepe.edu.tr http://dx.doi.org/.......
} 
that learners are expected to be more independent since education over technological tools is now providing huge amount of information, which making it possible for teachers to guide and advise online. Even though there are huge amount of online materials by leading publishers and news agencies (i.e. $B B C, V O A$ News, The Guardian, etc.) available on the Internet, serving for millions of users, these supplementary and open educational resources may not always correctly and efficiently meet the needs of certain number of learners. What is more, there are very few studies on efficacy of online materials produced after data collection processes on learning strategies of the learners. On the other hand, there are serious criticisms towards using online contents since they have very little contributions to radical changes in the traditional habits of the usual learners. Many of the online platforms are designed according to the desires and perspectives of their creators by disregarding learning strategies and level of knowledge of the learners.

Oxford (2001) clarifies that "if there is harmony between (a) the student (in terms of style and strategy preferences) and (b) the instructional methodology and materials, then the student is likely to perform well, feel confident, and experience low anxiety." (p. 359). The studies by Oxford (1990), Hismanoglu (2000), Hsiao and Oxford (2002) and Özmen (2012) just provide general categorizations of Language Learning Strategies (LLS) and instruction of LLS but it seems that some further research is highly needed to clarify how learners with different LLS behave in an online environment to automatize and use their LLS preferences for particular skills like online collaborative writing. The current study is a work running online platforms for writing skills of the learners with different language learning strategies and English language knowledge. The purpose of it is to figure out if EtherPad platform and collaborative writing tasks function well for the participants. The platform and tasks are designed according to learners' language knowledge. It also aims at observing and defining their language learning processes and exploring to what extent their learning strategies contribute to their collaboration. In this paper current trends and studies in the literature concerned will be reviewed first. This is going to be followed by declaring research questions and hypothesis. The following sections are going to clarify methodology of the research. Finally, findings and discussion sections will identify consequences of the study. Conclusion part is going to sum up underlying results and points of the study.

\section{Literature Review on Online Collaborative Writing and Language Learning Strategies}

Writing, and particularly assessing writing, has gained some new and important roles to play in language teaching within last decades (Behizadeh \& Engelhard, 2011; Raimes, 2000; Yancey, 1999) despite the fact that the acceptance of writing as a separate skill and discipline took a long time. Yancey (1999) defines that process as "the most important change in 50 years" in education ( $p$ 485). As a result of that process, writing assessment has become "a new expertise and a discipline", which should be "social specific, purposeful, contextual and ethical" (p. 486-500). She 
describes that process as "overlapping waves" even though there occurred certain radical changes in the perspectives within years (p. 483) (see also Raimes, 2000: 153163).

She categorizes these waves into three; the first wave is in 1950s-1970s and writing assessment was in "the form of objective tests" including multiple choice tests and focus on grammar. In the second wave (1970-1986), it was appeared as "holistically scored essay". And in the last one (1986-present) it was in the form of portfolio and programmatic assessment and collaborative scoring was essentially required for grading. Savignon (2000) has reported that "teachers, under pressure to make their students do well on [large-scale, standardized, multiple-choice] tests, often devote valuable class time to teaching test-taking skills, drilling students on multiple choice items about writing, for example, rather than allowing them practice in writing." (p. 78). Writing as a cognitive process in social and sociocultural contexts (Behizadeh \& Engelhard, 2011) currently has got a new status. Traditions in writing have shifted from form-dominated sentence drills, controlled compositions to content [context]/taskbased peer collaborated activities as Raimes (2000) notes.

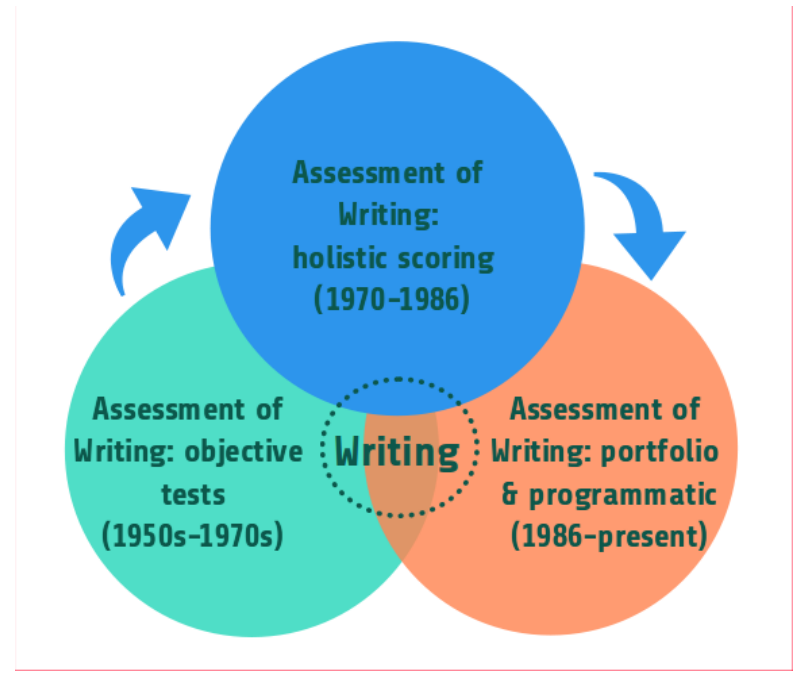

Figure 1: Improvement of writing as an assessed skill

Admittedly, technological developments and particularly online platforms have significantly contributed to teaching writing and assessing written texts. Specifically, online collaborative writing tools recreate all those ideas represented in the aforementioned studies. These tools have been improved and evolved in a very short time, and they enable learners to practice and learn more effectively. For example, a qualitative research conducted by Selçuk (2016) reveals that high school students using Facebook for online collaboration report peer collaboration is of "positive impacts on their writing development and self-confidence in writing English." (p. 5). The participants also find feedback from the group leaders are "instructional and motivating" (p. 5). In contrast to detailed studies on online collaborative or asynchronous joint writing (Ellis, 2006; Guasch, Espasa, Alvarez, \& Kirschner, 2013; 
Kim \& Eklundh, 2001; Limbu \& Markauskaite, 2015), it seems there is still very little emphasis on synchronous online collaborative writing (SOCW) ${ }^{2}$ in teaching English as a foreign language.

Integration of online collaborative word processors such as EtherPad, Goodle Docs and web collaborative authoring tools like Sweetie as part of blended writing environments for teaching and researching purposes has been gaining importance and popularity among the researchers (Gleason, 2014; Leeder \& Shah, 2016; Miura, 2016; Yadollahi \& Rahimi, 2015). Leeder and Shah (2016) summarise the advantages of collaboration in learning environments. For example, collaboration positively contributes to "critical thinking, better learning outcomes, deep learning, knowledge construction, sharing information resources and ideas, explore different viewpoints, evaluation of information and blending useful skills" (p. 203). The study by Leeder and Shah on collaborative information seeking via Coagmento plugin with EtherPad explores how university students collaborate for library researchers and the challenges they face during their efforts to find appropriate resources. Yadollahi and Rahimi (2015) find out that using EtherPad for collaborated writing tasks and peer feedback mechanisms positively affected writing skills in English for Iranian students.

Gleason`s (2014) research on classroom ethnography and writing developments in blended environments for Spanish writing course has come out with positive results in terms of integration of synchronous web tools into writing processes and engagement of students into blended writing practices. Gleason argues that participants can "keep their thoughts more organized" in the virtual environment used. Outcomes from the research support the idea that it is advantageous to use online editors in accordance with blended writing environments. Gleason also comments that:

By supporting students and facilitating the teacher's feedback on students' particular weaknesses and challenges, technology permitted students to engage with the course material, to take maximum advantage of their in-class writing time, and to exploit expert feedback. In light of the ways that a third-year FL course needs to unite students' knowledge of grammar principles with their applications in real texts, students connected their reflections about language to their active applications of linguistic principles.

On the other hand, the research on language learning strategies have seriously attracted attention of the researchers in the late $20^{\text {th }}$ century despite the fact that the relevant terminology and categorization of the strategies have often been under dispute for a long time. The studies in the early 1990s by Rebecca L. Oxford, J. O'Malley and A. Chamot are of leading positions to explain the role of LLS and

\footnotetext{
2 Online Collaborative Writing (OCW) is mostly used by the researchers in the literature but it seems that this does not meet what the author wants to mean in the current study because OCW can be managed by different users at different durations by means of other soft-wares and cloud technology like Dropbox, SpiderOak, etc. Therefore SOCW was purposefully preferred in order to emphasize the strength of a real-time editor for synchronous online collaborative writing activities.
} 
categorization of LLS types even though they have suggested various taxonomies and definitions (Ellis, 2008). According to Oxford's (1999) theoretical framework, LLS are of a lot to do with becoming proficient, autonomous, self-regulated and responsible learners. She has defined LLS as "specific actions, behaviors, steps, or techniques (...) used by students to enhance their own learning" (p. 109-110). She has also described six language learning strategies like cognitive, mnemonic/memory, meta-cognitive, compensatory, affective and social strategies (Oxford, 1999, 2001, 2003). These strategies are basically of diverse functions and meanings from the learning styles such as visual, kinesthetic, auditory and tactile, which refer to general tendency of choosing specific ways to learn (Lynch, 2004; Pashler, McDaniel, Rohrer, \& Bjork, 2008; Reid, 1987). That is, these LLS refer to the abilities and willingness summarized in Figure 2.

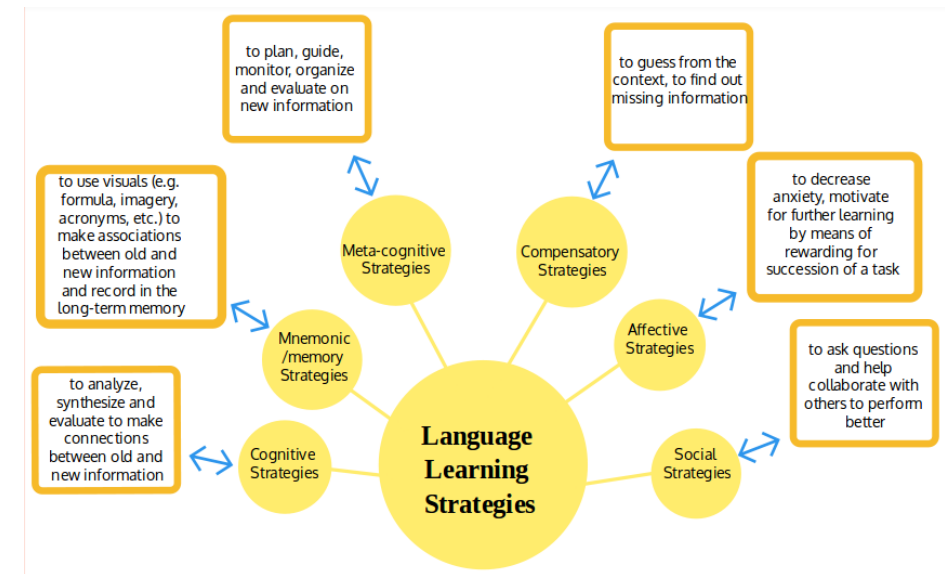

Figure 2: Types of Language Learning Strategies (Oxford, 1999, 2001, 2003)

Oxford (1999) has also called memory, cognitive and compensatory strategies as direct strategies and the rest as indirect strategies. Such strategies seem to help the learners take responsibility and position in problem solving and experience positive performance and success. Oxford (2001) states that "styles and strategies help determine a particular learner's ability and willingness to work within the framework of various instructional methodologies" (p. 365). However, these notions are not always clear cut and easy or simple to observe due to the fact that non-stop changes in behaviors, attitudes and experience of the learner as they find out and internalize new notions, and integrate themselves to novel conditions such as online environments. Some recent studies on LLS have focused on the categorization and instruction of the strategy types (Chamot, Meloni, Gonglewski, Bartoshesky, \& Keatley, 2011), however, there are informative studies which touched on problematic and some several contradictory points of such categorizations, which is beyond the content of the current study (Ellis, 2008; Rose, 2012).

All in all, obviously, the relevant literature is focusing on changing responsibilities, needs, perspectives and positions of the teachers and learners as well as categorization of LLS in the digital world as mentioned earlier and it is away from 
responding how personalized learning can be achieved considering learners with certain LLS in online environments.

\section{Research Model and Hypothesis}

Online environments and contents can be used as 'consciousness-raising device for learners' (Raimes, 2000) and to know learning strategies of the learners may considerably help both teachers and learners to find and create new paths to deal with the challenging learning tasks which need utmost problem solving and creative thinking skills. Similarly, to encourage learners for online collaborative learning over various web tools may come up with more positive results in term of successful completion of the tasks. Accordingly, there are many online platforms and multimedia tools such as key-pals, web-quests, and course management systems available to enjoy for that purpose (Pitler, Hubbell, \& Kuhn, 2012). On the contrary, there is very little research on the efficacy of online materials on the learners with different language learning strategies even though there are relatively more on strategy use in face-to-face teaching/learning environments, which are mostly quantitative studies to define strategies and literature reviews (Griffiths \& Parr, 2001; Hismanoglu, 2000; Özmen, 2012). In this regard, the following research questions were formulated for this study:

- a) Could the learners build up a collaborative discourse while writing in English in an online platform?

- b) How efficient are online materials on language learning processes of the students having different LLS?

- c) Could learners use their superior LLS for specific collaborative writing tasks in an online environment?

- d) Could learners with different LLS transfer knowledge over different tasks and skills?

- e) Is there prominent difference among the participants with different LLS in terms of their SOCW performance?

In this study, it has been hypothesized that online environments can be enjoyed by the learners with different LLS more efficiently on condition that they study in a learning environment without a grading system and are allowed to work collaboratively. Also, their LLS can be contributing to the achievement levels, which can clearly be diagnosed by means of online educational platforms. To put it differently, SOCW can contribute a lot to language development of the learners with different LLS as long as they are encouraged to use their LLS for a particular skill like online writing by means of peer works.

The research was conducted at a vocational school and took one month. The participants attended online courses in a computer laboratory with Internet access once a week. The scope of the current study was planned to promote their skills such as creative thinking, questioning, reading/listening and comprehension, and SOCW skills. The emphasis of the content of the online courses was on producing appropriate 
vocabulary, building background information and constructing cohesive paragraphs in a given context. The role of the language teacher was assigned as online moderator and facilitator. The participants of the research were expected to work collaboratively to produce paragraphs in a certain context in around two-hours-long sessions. The reasons behind requiring the learners to work together online was to assist them build their own mutual learning frameworks with new knowledge. By that way, a) they could "get additional ideas from their peers", b) they could "identify their mistakes", c) they could "encourage each other to do better", d) they could "share the work and complete the task more quickly" e) they could "share their thoughts and feelings" with lower anxiety, f) they could take advantage of "teamwork and (different) experience with unique brainstorming and thinking processes" to deal with learning difficulties (Lynch, 2004). In addition, the learners were not expected to attain any grades which would affect their motivation and learning process negatively, because, admittedly, the grades may not always reflect correctly if the learners have experienced real and permanent learning. In this sense, the current study did not focus on any exam-based success but attempt to clarify the efficacy of online learning through SOCW.

\section{Methodology}

In this study, both quantitative and qualitative research methodologies were integrally used in three phases. Before introducing the online courses, a questionnaire was formed in order to describe participants' demographic and educational profiles. A version of Strategy Inventory for Language Learning (SILL) by Oxford (1990) ${ }^{3}$ was used to diagnose the LLS of the participants. Oxford's six dimensional categorization was used in this study since it was more consistent, valid and comprehensive descriptor for the research when compared to other theories and models (Ellis, 2008; Hsiao \& Oxford, 2002). The participants also took a paper-pen Quick Placement Test 4 which helped to figure out their level of language knowledge. Hitit.Moodle 5 was employed as the online learning platform for this study.

The online contents were merely available for the selected group including voluntary students from the Vocational School. The online courses were composed of warm-up questions, listening, reading and comprehension questions and essay writing questions which required collaborative writing over a separate online platform called EtherPad. Responses from the participants to the essay questions were evaluated and corrected according to the following points: a) grammatical correctness, b) using appropriate vocabulary, c) organization of the paragraph, and d) using correct context. At the end of each session, paragraphs with appropriate

\footnotetext{
3 It was also published online over Olenka Bilash's web-site:

<http:/www.educ.ualberta.ca/staff/olenka.Bilash/best\%20of\%20bilash/SILL\%20survey.pdf>

4 Quick Placement Test Version - 1 was improved by Oxford University Press \& University of Cambridge Local Examinations Syndicate (UCLES) in 2001. The test is a trustful placement tool for institutions and/but it was used as a proficiency test in order to describe and define language knowledge of the participants.

5 See: <www.moodle.hitit.edu.tr>
} 
corrective and suggestive feedback were sent back to the participants. Frequencies of active participation, number of sentences produced and time spent were calculated and compiled in a LibreOffice excel file, and averages of each aspects per session were calculated in order to diagnose differences between the participants with certain LLS in terms of their performance.

\subsection{Participants}

Students $(N=45)$ enrolled at the vocational school filled up the questionnaire for profile and $S I L L$ before participating in the research. Voluntary participants $(N=22$, females $=18$, Males $=4$ ) were assigned to take part in this research. They were first year students, who were registered at various departments. They were all native speakers of Turkish and learning English as a foreign language. The age of the participants changed from 18 to 26 . They completed their high school education at vocational high schools $(N=13)$, regular high schools $(N=4)$, Anatolian high schools $(N=4)$ or religious vocational high schools $(N=1)$. Almost all of the participants were of educational experience in Turkey rather than only one female participant who lived and took education at university level for several terms in Germany. Some of the participants $(N=8)$ took an English preparation class during their high school education. They took and passed a face-to-face English course in the Fall 2014 term before joining in the research at school. They used a learning management system, Oxford English Language Testing 6 , to practice English as part of their formal English course and language curriculum at school for almost six months. Online activities in the LMS were including practice items for reading, listening, speaking and individual writing.

According to data from SILL conducted for these participants, their LLS were described as social strategies $(N=7)$, compensatory strategies $(N=4)$, memory strategies $(N=4)$, affective strategies $(N=3)$, cognitive strategies $(N=2)$, meta-cognitive strategies $(N=1)$ and meta-cognitive and social strategies $(N=1)$. The level of their language knowledge were A1 $(N=15)$ and A2 $(N=7)$ according to language test. Overall superior LLS was defined as affective strategies (AS) (3.6) even though the most frequent LLS was determined as social strategies (SS) (seven participants with SS). As it can simply be figured out from the table, none of the participants always or almost always use a particular LLS, but most of them $(N=13)$ enjoyed them in medium or just above medium levels (See Table -2 in Appendix -1 ).

\subsection{Data Collection Instruments}

A questionnaire for profile description and SILL survey were designed and formed over Google Drive by the researchers. A pen-paper language test, Quick Placement Test-Version 1 (Part 1), was used as a proficiency test in order to clarify their level of language knowledge. The online courses were created over Hitit.Moodle and forum, chat, lesson and quiz modules were mostly employed. Question types such as 
description, true-false, multiple choice, matching and essay writing were set inside those modules (See Screen-shots - 1, 2, 3, in Appendix - 2). Reading materials and listening records with zero level of English were adapted from Breaking News English web-site ${ }^{7}$. These materials were particularly designed for those participants regarding their levels of language knowledge as well as their potential learning styles like visual and auditory. The participants were encouraged to use chat module in order to promote their lexical faculty, level of comprehension and cooperative skills. EtherPad, web-based collaborative real-time editor, was intentionally used for this study. Separate EtherPad links were given to each randomly selected peer who was defined in different colors in the system (See Screen-shot -4 in Appendix - 2). The peers could chat and write simultaneously over EtherPad's editor and chat-box. The peers were provided with writing questions and they were expected to collaborate to respond and write paragraphs with at least ten sentences in 45 minutes. All the writing processes were recorded over EtherPad's system for teacher's evaluation, analysis and feedback (See Screen-shot - 5 in Appendix - 2).

\subsection{Instructional Design}

Synchronous online learning was taken as the leading teaching method in this research. The online courses were generated by regarding lower anxiety levels and higher intrinsic/extrinsic motivation, and so they were independent of any formal grading system as part of their formal English language course. By this way, the participants were encouraged to make as many mistakes as possible since the mistakes were idealized as unique opportunities for getting detailed feedback from the teacher and their peers for further collaborated learning. Perhaps, it is more influential for learners to get feedback from the teachers in especially asynchronous studies but it was estimated that corrective feedback from their peers could be more encouraging and less time taking in this study. The reading topics used in online courses were contextually in parallel with those for writing performance. The grammar topics were more or less the same as in the face-to-face courses. However, any new grammar topic was not taught or repeated over and over during online learning processes. The content of the online courses was designed by following steps: a) warming activities with 3 or 5 individual writing questions, b) listening activities with 4 or 5 multiple choice questions, d) reading activities with comprehension questions, and e) essay questions based on the contexts represented in the reading part.

The writing activities were presented over EtherPad's web-site and the peers were asked to complete the writing tasks by collaborating in given time. Traditional teaching methodology, in which the teachers are in an active role and only in a nonstop talking position, and the learners are in passive listener roles, was not employed in this study. The teacher only helped to the peers when they asked questions over chat module and particularly when they lost their way in the web sites. The peers 
were supported to work together and ask any questions to each other over chat-box of EtherPad but the teacher did not check and intervene in the process while they were constructing their texts. The peers were allowed to use online dictionaries and web sources in order to learn new words and get information and produce paragraphs by enjoying their own words and sentences.

\subsection{Procedure and Data Analysis}

The level test in the pen-paper format was held in classroom environment and took around 30 minutes. With the test, the purpose was to create a homogeneous group for the project in terms of language knowledge. Online materials were represented only for voluntary participants with certain level of English knowledge and those who did not take the test were disregarded. Learning strategies of the learners were defined online by SILL presented over Google Drive. As a result of the diagnosing questionnaire and definition of the learning strategies, those participants who did not have any interest to the research and use any specific strategies were not included in the group. The participants took the online courses in a computer laboratory located inside the school. Twenty-one of the participants attended at least two sessions of the courses and one participant visited the course just once. Four course sessions were completed in a month. The courses took around two hours for them to complete all the tasks. Just after completion of the warming up activities, listening and comprehension questions, the participants were randomly grouped into peers composed of two learners to write collaboratively over EtherPad. Forty-five minutes were given for them to do independent collaborated writing task, but the duration limit was not strictly obeyed in order not to influence their motivation negatively. The peers were allowed to use other web-sites and online dictionaries to take information and enrich the content of their paragraphs.

The participants were asked to write a paragraph with at least ten sentences in a certain context regarding the question(s) given. Writing topics were limited to argumentative topics like advantages and disadvantages of technological devices, increasing use of computer and internet, extinct animals, using online materials for education. These topics, which were contextually close to each other as well as to the reading topics, were intentionally chosen in order to help the participants memorize appropriate words and grammatical structures while sharing their ideas with their peers and structuring, revising their paragraphs. The teacher did not intervene in the process of writing over EtherPad's chat-box but responded questions of the participants by means of chat blog of the LMS. The written and recorded paragraphs over EtherPad were later evaluated and corrected by the teacher, and then they were all both sent into participant's accounts and uploaded into forum module in order for all the participants to see the written and corrected paragraphs. They could also see their earlier productions when they entered into their EtherPad accounts. The paragraphs were later statistically evaluated in terms (a) participants' participation in paragraph production, (b) number of produced sentences and (c) time spent for 
paragraph production by means of a Libreoffice excel document ${ }^{8}$. Considering these aspects, all of the averages of the participants' aspects were calculated and represented in summarizing graphs.

\section{Findings}

Personal writing is not a simple process but it is a result of set of cognitive processes benefiting from personal ideas, competence, creativity, imagination and further abilities like critical thinking. It becomes more difficult when it comes to online collaborated writing since the peers should necessarily produce language patterns; improve/use strategies and ideas to support the main ideas specifically written in a certain context. The data including responses to warming questions, listening, reading and comprehension questions collected by means of Hitit.Moodle indicated that the participants have noted utmost willingness to learn over online materials. Although it was discernibly a big challenge for each peer to write the very first words and sentences, taking turns, correction of the mistakes and spending effort for clarification of the ideas, the peers could improve a successful online collaboration. They could integrate themselves to the online environment and use the tools for the sake of language learning. Interestingly, they could internalize the tasks in a very short time and did not ask many directing questions after the first week's session. They encouraged each other to take turns and responsibility to complete the tasks within the given duration. Some further findings were summarized under two main titles below.

\subsection{Collaborative Discourse}

The first research question of the study was dealing with if the participants come up with a collaborative discourse while writing in English in an online platform. They mostly attempted to learn the unknown vocabularies and syntactically correct sample sentences to improve their writing skill even though the language they enjoyed to communicate over chat-box was mostly in Turkish. For example, a peer of participants noted the following dialogue in the very first session of the course:

[14:25] P1: asll :D [name of the peer]

[14:25] P6: what banu [name of the peer]? :D

[14:27] P1: zmankaybu ne demek? [What does "waste of time" mean in English]"

The peers spent considerable time to find out new vocabularies, build up syntactic frameworks to express their ideas and appealed to some interchanging questions to plan what they wanted to mean before starting to write. For instance, following peers produced the following sentences:

[14:24] P5: kanka ne yazalım [buddy, what shall we write?]

[14:24] P5: I think diye başlayalım [let's begin with "I think"]

[14:24] P10: okey :)

\footnotetext{
${ }^{8} \mathrm{~A}$ value (1) was given for each attempt of the participant to produce a sentence, a produced sentence, and the time was calculate as minutes that they spent on the work.
} 
[14:24] P5: dezavantajlarinu soruyor [it is asking for the disadvantages]

[14:25] P10: elektronik aletlerin [of the electronic devices]

[14:25] P10: o zaman biz de yazarlz [then we can write]

[14:27] P5: damage to the brain

As it can also be observed in the dialogues above, the participants could build up a collaborative discourse over the EtherPad in spite of the fact that they had a great challenge to produce well organized paragraphs. They actually experienced difficulties in writing coherently and cohesively correct paragraphs having logically fluent and accurate sentences. For instance, occasionally, some of the participants could not notice how to start a paragraph, where to introduce topic statement, when to provide supporting examples. On the other hand, some of the participants however tended to produce their paragraphs separately without intervening in each other's blocks of paragraphs while some others learned how to benefit from each other's knowledge, correct mistakes and give positive feedback (See Screen-shots -7 and 8 in Appendix 2).

It is also worth having a close look at the level of writing skills beforehand. Collaboratively produced paragraphs showed that the participants had certain level of (but still improving) writing skill, which is actually between intensive and responsive writing according to Brown and Abeywickrama's (2010) four-dimensioned categorization but not certainly above that. The participants could write appropriate words in a certain context and use collocations (e.g. spend a lot of time, fast food, waste of time, away from, financial problems, adverse effects etc.) and quasi-correct grammar to convey the meaning for the situational context. They could connect sentences to each other and write paragraphs, and engage to each other's ideas to build up further supporting examples despite the fact that they noted many mistakes in terms of spelling, punctuation, sequence of ideas.

Separate chat activities were initiated for the participants to communicate with each other and the teacher for each session over Hitit.Moodle, but most of the participants tended to use the chat-box of EtherPad. The participants noted entries in order to ask for Turkish or English meaning of certain words and phrases. Most of the time, the participants preferred using chat-boxes over EtherPad so that they could mainly build up their paragraphs and produce appropriate discourses to initiate new ideas and suitable components. They could write at a slow rate of speed and use appropriate word orders in English grammatical systems. They could express particular meanings in different grammatical forms. Interestingly they could become aware of other grammatical rules such as comparative forms of adjectives and new syntactical orders in sentence level like passive voice, when clauses, modal verbs (e.g. be able to, need to, will, would, should, must, etc.), relative pronouns/clauses (e.g. who, that, etc.) and learn how to combine them without any grammatical explanation from the lecturer. They could enjoy using cohesive devices (such as because, but, and, therefore, due to, because of, thanks to, such as, etc.), adverbs (e.g. early, slig[h]tly, especially, very often, before, previously, initially, really, commonly, usually, etc.) and 
conjunctions (e.g. both ... and, and, etc.) which they did not exactly learn during the face-to-face courses in the content and scope of the formal curriculum.

In the macro level, the learners could use rhetorical forms and conventions of written discourses such as description and argumentation to support their ideas. They took advantage of communicative functions of the written texts. They could convey links and connections between the main ideas, supporting ideas and new information by means of linking words like such as, also, and, etc. They could distinguish between the literal and implied meanings. For example, one of the participants wrote that "People in the future go wrong ways." They could use culturally specific references. For instance, a participant attracted attention to a common belief for the use of Internet by noting that "Because evil thoughts can appear harmful information causes harmful habitis [habits].”. They could develop writing strategies such as using paraphrases, synonyms and feedback for revising. For example, one of the peers paraphrased information dealing with extinction of animals by writing that "Many animals were extinct before the appearance of the first generation of people. The causes of both people and nature is located. For example, Anatolian tiger is extinct killed in 1970.”.

The participants noted numerous grammatical and syntactical mistakes such as subject-verb disagreements, tense disagreements, misspellings, missing punctuations, sentences without subjects or verbs, etc. It was frequently realized that they focused more on negotiations to find out the information and meaning appropriate for the content/context which helped them express their ideas effectively. Therefore, it seems that finding correct forms became of secondary importance for the peers.

Vocabulary and knowledge transfer from the earlier reading passages were dramatically very limited and the peers preferred to find out new ways and information to improve their writing. The transfer from Turkish language was however little visible. For example, some of the language transfers by the participants are listed below.

"The age limit should be."

"People doing asosyel."

"People in the future go wrong ways."

"[...] can suggest; Facebook, Twitter, Oyyla, Messenger, Digg, Myspace. tumblr, sour dictionary, Moodle, oxford İngilizce testing, gmail, yahoo, skype [...]"

"Cetles to enter the sites we find new sites to new places."

One of the participants, who lived in Germany for some time, used German counterparts such as follows below for English words.

"people speaking out their family mit moblle phone mit computer"

"The people think is tegnology for selbest lives"

\subsection{Close Look at Aspects of LLS}

The second question was about to what extent online materials are efficient on language learning processes of the students having different LLS. The participants with different LLS evidently spent prominent effort to deal with the learning problems and completion of the tasks on time. The participants with AS noted an 
average, which is not less than 11.67 for each aspect and those with MEM S recorded not less than 9.00 while the participants with SS scored not less than 6.29. All of the participants spent 8.61 minutes to complete the writing tasks on average (see Graphs -1 and 2 in Appendix - 3). As it can be inferred from the Graphs on LLS and session based averages, the participants got different averages depending on their numbers, which provided promising idea about their real performance of collaborated writing during the online course.

The third question was investigating whether participants could use their superior LLS for specific collaborative writing tasks in an online environment. Although it was comparably challenging to diagnose these strategies in the written plain texts in a short time, it could be determined in the dialogues that they produced while producing the language patterns in English. The peers noted real engagements to plan and organize the paragraphs together. For example, the participants with SS wrote the following sentences in the chat-box of EtherPad:

[14:23] P15: nasil yapicaz fatih [how shall we do that fatih]

[14:24] P20: ben sen cumlelere a baktım yanlıs bise yok kl [I have checked your sentences, there is nothing wrong]

[14:25] P15: dur anladım 1 dakika biz cevapları kendimiz sıra halinde yazmışız ya öyle olmuycak senin 1. Sorunla benim 1. Sorumu birleştiricez galiba [stop I got it, a minute we wrote the sentences in an order, it is not like that, apparently we should combine your and my responses for the first question]

They supported each other to produce meaningful and useful ideas to use in their paragraphs. More importantly, they frequently asked questions to understand each other and introduce their own knowledge. The following dialogue between peers with SS shows that they did not tend to move forward without being certain about what is asked.

[15:07] P11: 2. Soru nesli tükenmekte olan hayvanlar içim neler yapabiliriz dıyo demi [the second question asks that what we can do for extinct animal, doesn't it?]

[15:12] P15: evet [yes]

[15:13] P11: 3 soruda ne diyoo [What does the third one ask?]

[15:15] P15: 4. Soruyu anladin $\mathrm{ml}$ ? [Did you get the fourth question?]

The fourth question was on the transfer of knowledge by the participants over different tasks and skills. The platform allowed them to benefit from peer learning for certain contexts. They were able to organize, plan and write what they thought about the writing topics by cooperating to each other. It seemed that the LLS supported participants to transfer their knowledge. The participants often visited other websites and online dictionaries such as Google-translate, Tureng, etc. to find out new information and potential words suitable for the context. They enjoyed writing collaboratively when especially they built up the correct and full sentences to share and brainstorm their ideas. For example, a peer of the participants came up with the dialogue below in the third session of the course:

[15:07] P18: Başlı̆̆ın Türkçesi nedir? [What does that title mean in Turkish?]

[15:07] P6: Nesliniz tükenmesin gibi birşey :) [something like "no extinction"]

[15:07] P18: Hayvanlanların nesli tükenmesin diye gibi birşey . [something like "no extinction of animals] 
[15:18] P18: Bazl hayvan türlerinin insanların ihtiyaçlarını giderdiği için biz insanlar bu hayvanların nesillerini tüketiyoruz diye bir cümle. [A sentence like this; we cause animal extinction because some of animal kinds meet the needs of human beings]

[15:20] P6: bn de şimdi şey yazdlm nedenleri arasında hem doğa hem insane yer allyor örngn anadolu kplanı dddim [I also wrote something for the causes, both nature and human take place, for example I wrote Anatolian tiger]

[15:23] P6: ?

[15:23] P18: Güzel cümle olmus :) [it is a nice sentence]

[15:29] P6: başlıtkta of animals var ya sil sen yaz o kısmını ortak olsun :) [There is "of animals" in the title, delete it and write again and then it becomes mutual]

[15:30] P6: :))

[15:30] P18: :)

The participants evidently did not always tend to use the information belonging to the online course contents and prior face-to-face courses but interestingly tried to use new meanings, forms and data that they found out over Internet. It was also observed that they divided some tasks into parts and tried to perform individually particularly when they found out new information to construct the paragraph. The participants tended to use particular language patterns to encourage their peers to take turns. By that way they decreased the level of anxiety and stress while working collaboratively to arrange and exchange information. They strictly followed a sequential way while completing the tasks. Also, they checked their productions and provided positive feedback for each meaningful pattern. One of the examples by the participants with SS for that condition is as follows:

[15:14] P20: Nesli tükenen hayvanlart korumak, ilk olarak yalnızca belirli kuruluşların, kurumların görevi değil; dünyayı seven ve doğasına sahip çıkmak isteyen her bilinçli kişinin yapması gereken bir şeydir [Initially, to save extinct animals is not only the task of definite institutions but also it is something that every conscious person, who loves the world and wants to protect nature, should do.]

[15:14] P20: şunu yazdım [I wrote that]

[15:15] P14: SÜPER OLMUŞ :) [It is perfect :)]

[15:18] P20: sorularl ben buldum :) [I found the questions]

[15:19] P20: 1, 2, 3 soruları tamam sen 3.soru ıle ılgılı bıseler yaz sonra 4 üyapalım [1., 2., 3. questions are completed, you should write something dealing with the third question then we complete the forth.]

[15:20] P14: tamam sen istersen 4.yapa dur ben 3e eklerim [If you wish, you can do the forth one, I will add something to the third one.]

The last question was seeking if there is prominent difference among the participants with different LLS in terms of their SOCW performance. The analysis proved that those participants with MEM S dramatically decreased their performance in participation in paragraph production and number of produced sentences as well as the time spent while the ones with SS notably increased their performance in all aspects and particularly in participation and time spent. Most of the other participants with AS and MET S noted very fluctuating results but the ones with COG S and COM S had almost very low and stabilized averages in participation in paragraph production and the number of produced sentences (See Graphs 3, 4, and 5 in Appendix - 3).

As a consequence of the data by the participants, it is undoubted that their fourweek-long experience with online materials helped them become aware of their 
potential learning strategies. Clearly, they had positive tendencies towards the online learning environment and took promising positions to each other to create encouraging dialogues. Particularly they attempted to learn by themselves and work together to come up with better performance for each task. They markedly tended to realize learning processes based on exploration of new knowledge and structures, curiosity and willingness to cooperate.

\section{Discussion}

It seems that new technologies always put new burdens both on the teachers and learners. Both sides should now pay much more attention to support each other outside the classrooms, and take responsibilities to teach and learn independent of exams and certificates. There are serious arguments about the efficacy of the online learning, which was mentioned by Vardi (2012) and Herold's (2015). However, as a result of detailed observations and data from the current study, it can be inferred that integrating collaborative online materials is efficient on language learning processes of these participants with different LLS. The volunteered participants made a considerable effort and time to complete the online tasks and collaborate with their peers to learn further.

It became obvious that the language that the participants used to communicate to each other and to build up linking paths between their ideas and possibly learning strategies was very informative in terms of visualizing their superior LLS. The data from the participants' performance supported definition of LLS in Oxford's classification table, in that the participants with SS noted visible online collaboration and an increasing performance during the research. It seems that it is a promising idea and teaching strategy to make learners with different LLS to work together and to enable them to improve their LLS through SOCW activities. Therefore, some learners could use their superior LLS for SOCW in the online environment.

The analysis of the texts by the participants inferred that the participants often focused more on linking appropriate 'meaning' with 'forms'. They could express their ideas and form their paragraph planning and organizations by means of these new forms that they needed to convey what they wanted. Lynch's (2004) foresights about using online materials is reportedly correct, and the participants noted a lot of learning processes, which directed them to be as autonomous as possible by working together. Presumably, online learning is of a unique role to play in being autonomous learners because it creates a short and visible path for them to go beyond learning over "classically and ideologically standardized or ready-made curricula designed by the state and curriculum developers" (Apple, 2012, p. 188-200) who may not know enough about students' individual needs and LLS.

As Ellis (2008) and Ellis and Widdowson (2003) report, the personal and situational factors such as individual differences (e.g. age, gender, attitudes, personality types, earlier educational experience), motivation, the type of task given had determining parts to play in the use of LLS among the participants, and indeed the observations 
showed that the peers effectively transferred specific knowledge through online collaborative tasks. The participants often managed to employ their superior LLS and reconstruct the system of their thoughts according to their needs.

The correlation between second/foreign language proficiency, success and LLS was highlighted in the study. Also, online collaborative learning without any ground for formal grading, stress and anxiety provided an autonomous learning experience with higher motivation. Admittedly, the participants made various grammatical and lexical mistakes due to perhaps their low level of language knowledge and missing adequate educational experience; however, they cooperated to overcome these mistakes and encouraged each other.

Needless to say, learning how to write may take very long time and need a lot practice for usual learners as Howe (2000) clarifies. Unlike, EtherPad's synchronous platform enabled adequate flexibility for the participants to collaborate, think over and over before producing words, sentences and paragraphs in a short time. The data came up with the idea that the learners with different LLS could simply use their LLS according to the learning tasks and their needs depending on the conditions. The active interaction between the peers developed initial engagements on the online platform. As a result, the participants spent considerable effort to learn new words, investigate and practice new grammatical rules through EtherPad's chat-box and real-time word editor.

Savignon (2000) states that "communication cannot take place in the absence of structure, or grammar, a set of shared assumptions about how language works, along with willingness of participants to cooperate in the negotiation of meaning" (p. 79). Moreover, Nunan (2001) remarks that acquiring a language goes through engaging in communication. Savignon and Nunan's arguments cannot evidently be dissociated from a) learning environment, b) teaching materials used, c) position of the teacher and, more importantly, d) LLS which should necessarily and consciously be considered. The participants got positive feedback from each other and invested on improving their LLS in every session of the online course. Actually, they both cooperated and combined their LLS to deal with the learning problems and to write proper responses according to the given questions. The graphs provided some significant hints about the participants changing performance within sessions even though the initial graphs may not seem that informative. The data from their average scores indicated that certain participants with MEM S and SS behaved in different ways and SS came up with increasing performance levels when compared to other participants. This may refer that the participants with SS can integrate themselves into online environments and benefit from learning process in a more effective way. Also, the average scores showed that the participants with other different LLS may need more support in order to improve their skills and knowledge.

Vardi (2012) and Herold's (2015) allegations about the efficacy of online materials, exam and certificate based programs fail to notice if the online course contents are designed according to learners' needs, learning strategies or not, which will evidently 
cause changes in traditional learning habits in a short-term application as the current study proves. Even though tests and exams are taken as encouraging and motivating assessing tools for learners, they might also cause negative wash-back on future learning if the learners internalize and remember incorrect answers as free of error items (Howe, 2001). Additionally, in his study on the perspectives of foreign students enrolled as full time students without any needs analysis and professional assistance at a Turkish university towards distance education platform and tools, Coşar (2015) reveals that foreign students face many challenging situations including, integration problems, absence of curricula in their mother language or in English and real 'interactions with their peers' while using distance education system of the university. Blackboard and Project Tomorrow's report alleges that "the ultimate innovative learning environment for today's student is therefore not predicated on the availability or access of emerging digital tools, but more importantly on the effective utilization of those tools to fulfill this student vision". Integration of online contents and digital tools into teaching is not an 'event' but a very 'sophisticated process" ( $p$. $12)$.

Savignon (2001) mentions that the teaching programs, which have been successful, always considered affective and cognitive aspects of language learning, and they covered psychological and intellectual capacities of the learners. Responses from the participants, their positive attitudes towards the learning environment and goaloriented self-regulation considerably espoused what Savignon means. In their study on students' conceptions of OCW Limbu and Markauskaite (2015) conclude that "a large number of participants saw OCW as a task to produce a written document, that is, to demonstrate what they already know or are capable of doing rather than learning." (p.404). However, task and skill based SOCW in the current study substantially provided an important ground for scaffolding and enabled the participants strengthen their motivation for coordination and learning over collaboration.

Various studies just focus on user attitudes and other aspects such a design of collaborative writing environment and feedback issue (Guasch et al., 2013; Kim \& Eklundh, 2001; Limbu \& Markauskaite, 2015) but language learning outcomes of the participants remain comparably unclear. These studies are also limited to user conceptions and perspectives, experimental research on what the learners actually learn through collaborative writing are missing. By the current study, the participants were put at the center of learning processes and particularly encouraged to use their LLS. The study largely clarified the link between the efficacy of online materials, especially SOCW, and quantity and quality of learning outcomes.

In their study, Kim and Eklundh (2001) observed the collaborated documents were mostly under control of a single person. It was also a situation what the participant tended do but was not that frequent because of the design of EtherPad's editor in the current study. Mostly the participants managed to produce their works in an appropriate mutual context that they attained while doing practices. The participants mostly shared some very new phrases, collocations and verbs with prepositions (such 
as to be under danger, in danger of, harmful for, dangerous for, make it easy, do research) with each other according to the topics. All these may indicate that they can transfer the knowledge from skill to another under the conditions they were provided during the online courses.

\section{Conclusion and Recommendations}

All in all, there happens a boom in the integration of technology into learning environments in the last decades. Several issues such as collaboration, communication, creative and critical thinking over technologically supported tools are on the agenda of the learners, teachers, researchers and curriculum developers. For that purpose, increasing numbers of learners are getting into contact with different online contents on the Internet.

However, there are still ongoing discussions about the use of online materials. Some of the researchers criticize the way of representing online contents without regarding learner's needs and motivation. Nevertheless, supply and demand equilibrium came up with radical changes in terms of the positions the teachers, learners and design of the curricula. The studies on LLS have also contributed a lot to the field and the current study has been a research on the efficacy of online materials and LLS used for particular tasks over the online environment. According to the results mentioned in detail above it supported the idea that online materials and platforms can effectively be implemented by the learners with different LLS. In addition, the learners could particularly improve certain LLS and benefit from autonomous learning while experiencing SOCW tasks but it obviously needs more experimental studies to prove whether learners with certain superior LLS could switch on the other LLS depending on type of the tasks and activities while learning language via online platforms. However, the difference in the performance of certain participants with different LLS illustrated that such attempts for online learning can simply be used to diagnose changes among LLS and manipulate their learning processes in order to help them improve their particular language learning skills.

Perhaps one way to cope with these non-intended outcomes and low performance from learners, called as digital natives nowadays, is to let them use their learning strategies flexibly and cooperatively by means of creating online platforms presenting challenging, problem or topic-based tasks that they could work together to think critically and organize accordingly. To put it differently, the learners should be encouraged to take advantage of specific and superior LLS by their peers and teachers as their partners while learning English because without no doubt there is a close link between strategy use and learning processes. The learners may also benefit from such online systems encouraging them for cooperative learning process as well as transferring knowledge interchangeably in different skills and learning new language structures without facing negative face from the lecturers and classmates in any classroom atmosphere. In this sense, we think that the study may contribute to the field and provide new perspectives for potential learners and teachers. 


\section{Acknowledgements}

We hereby declare that this study is our unaided work and that this paper has not been submitted for any other degree or award before. This research was financially supported by TÜBİTAK in scope of National Scientific Meetings Grant Programme. The paper is an open access study and can be accessed by all interested researchers, teachers and learners. All participants of the study were signed a consent form confirming their voluntary contributions, and their demographic data and ID were anonymously kept in the paper. The participants were not given any grade or reward for their attendance. For all materials including SILL survey, EtherPad platform, and course materials by Breaking News English necessary information about the scope and aim of the research was given for the owners of original works, which were mentioned in the bibliography. Permissions were taken for SILL survey and course materials by Breaking News English. And those materials were not used for commercial purposes but for only the current academic research. We hereby thank all voluntary participants and Çetin Kolkaya, M.A., Deniz Büyüker, B.A. and Adriana Ferreira R.S. Silva, B.A. for their unique contributions, feedback and comments about the paper.

\section{References}

Apple, M. W. (2012). Eğitim ve iktidar (Education and Power) (2nd ed.). İstanbul-Turkey: Kalkedon Yayıncilık.

Behizadeh, N., \& Engelhard, G. (2011). Historical view of the influences of measurement and writing theories on the practice of writing assessment in the United States. Assessing Writing, 16(3), 189-211.http://doi.org/10.1016/j.asw.2011.03.001

Bilash, O. (2009) Strategy inventory for language learning (SILL). [Available online at: http://www.educ.ualberta.ca/staff/olenka.Bilash/best\%20of\%20bilash/SILL\%20survey.pdf, Retrieved on Jan. 05, 2015.]

Blackboard, \& Project Tomorrow. (2015). Trends in digital learning report (Online Report). Blackboard \& Project Tomorrow. [Available online at: http://bbbb.blackboard.com/projecttomorrow-2015?s=web, Retrieved on Sep. 09, 2015.]

Breaking News English. (2014a). Course material-1. Texting while walking is dangerous [Available online at: http://www.breakingnewsenglish.com/1403/140312-texting-whilewalking-0.html, Retrieved on Feb. 14, 2015.]

Breaking News English (2014b). Course material-2. People use technology more, sleep less [Available online at: http://www.breakingnewsenglish.com/1408/140809-sleeping-0.html, Retrieved on Feb. 14, 2015.]

Breaking News English (2013a). Course material-3. Galapagos tortoises out of danger [Available online at: http://www.breakingnewsenglish.com/1312/131224-news-0.html, Retrieved on Feb. 14, 2015.]

Breaking News English (2013b). Course material-4. Studying with news in English class is useful. [Available online at: http://www.breakingnewsenglish.com/1312/131224-news0.html, Retrieved on Feb. 14, 2015.]

Brown, H. D., \& Abeywickrama, P. (2010). Language assessment: principles and classroom practices (2nded.). White Plains, NY: Pearson Education ESL. 
Brown, J. D. (1995). The elements of language curriculum: a systematic approach to program development. Boston: Heinle \& Heinle.

Brown, J. D. (2009). Foreign language and second language needs analysis. In M. H. Long, \& C. J. Doughty, The handbook of language teaching (pp. 269-293). Chichester, U.K.; Malden, MA: Wiley-Blackwell.

Chamot, A. U., Meloni, C. F., Gonglewski, M., Bartoshesky, A., \& Keatley, C. (2011). Developing autonomy in language learners learning strategies instruction in higher education. USA. [Available online at: http://www.nclrc.org/guides/HED/, Retrieved on Jun. 06, 2015.]

Chapelle, C. A. (2006). Autonomy meets individualization in CALL. Melanges CRAPEL ${ }^{\circ}{ }^{2} 8$ TIC etautonomiedansl'apprentissage des langues. [Available online at: http://ortolang.fr/IMG/pdf/melanges/5_CHAPELLE.pdf, Retrieved on Jul. 16, 2013.]

Coşar, M. (2015). Perspectives of foreign students towards distance education. International Journal on New Trends in Education \& Their Implications (IJONTE), 6(3). [Available online at: http://www.ijonte.org/FileUpload/ks63207/File/18.cosar.pdf, Retrieved on Sep. 05, 2015.]

Ellis, R. (2008). The study of second language acquisition. Oxford University Press, USA.

Ellis, R. A. (2006). Investigating the quality of student approaches to using technology in experiences of learning through writing. Computers \& Education, 46(4), 371-390. http://doi.org/10.1016/j.compedu.2004.08.006

Ellis, R., \& Widdowson, H. G. (2003). Second language acquisition (9thImpression). Oxford: Oxford University Press.

Gleason, J. (2014). "It helps me get closer to their writing experience" Classroom ethnography and the role of technology in third-year FL courses. System, 47 (Supplement C), 125-138. https://doi.org/10.1016/j.system.2014.09.023

Griffiths, C., \& Parr, J. M. (2001). Language-learning strategies: theory and perception. ELT Journal, 55(3), 247-254. http://doi.org/10.1093/elt/55.3.247

Guasch, T., Espasa, A., Alvarez, I. M., \& Kirschner, P. A. (2013). Effects of feedback on collaborative writing in an online learning environment. Distance Education, 34(3), 324338. http://doi.org/10.1080/01587919.2013.835772

Herold, B. (2015, June 11). Why Ed Tech is not transforming how teachers teach. Education Week. [Available online at: http://www.edweek.org/ew/articles/2015/06/11/why-ed-tech-isnot-transforming-how.html?tkn=SSYFLVExXA9Rje8yf2R4RakspGr7jbWQXGKa\&print=1, Retrieved on June. 12, 2015.]

Hismanoglu, M. (2000). Language learning strategies in foreign language learning and teaching. The Internet TESL Journal, 6(8). [Available online at: http://iteslj.org/Articles/Hismanoglu-Strategies.html, Retrieved on May. 20, 2015.]

Howe, M. J. A. (2001). Öğrenme psikolojisi (A teacher's guide to the psychology of learning). İstanbul: Alfa Basım Yayım Dağıtım.

Hsiao, T., \& Oxford, R. L. (2002). Comparing theories of language learning strategies: a confirmatory factor analysis. The Modern Language Journal, 86(3), 368-383. http://doi.org/10.1111/1540-4781.00155

Kim, H.-C.E., \& Eklundh, K. S. (2001). Reviewing practices in collaborative writing. Computer Supported Cooperative Work (CSCW), 10(2), 247-259.

Leeder, C., \& Shah, C. (2016). Library research as collaborative information seeking. Library \& Information Science Research, 38(3), 202-211. https://doi.org/10.1016/j.lisr.2016.08.001

Limbu, L., \& Markauskaite, L. (2015). How do learners experience joint writing: University students' conceptions of online collaborative writing tasks and environments. Computers \& Education, 82, 393-408. http://doi.org/10.1016/j.compedu.2014.11.024 
Lynch, M. M. (2004). Adapting your learning style to the online environment. In Learning Online: A guide to success in the virtual classroom (pp. 128-145). New York: Routledge.

Miura, M. (2016). Sweetie: Lightweight Web Authoring Environment. Procedia Computer Science, 96 (Supplement C), 887-895. https://doi.org/10.1016/j.procs.2016.08.267

Nunan, D. (1989). Toward a collaborative approach to curriculum development: a case study. TESOL Quarterly, 23(1), 9-25. http://doi.org/10.2307/3587505

Nunan, D. (2001). Syllabus design. In M. Celce-Murcia (Ed.), Teaching English as a Second or Foreign Language (Vols. 1-3, pp. 55-65). Boston: Heinle ELT.

Oxford, R. L. (1990). Language learning strategies: What every teacher should know (1sted.). Boston, Mass: Heinle ELT.

Oxford, R. L. (1999). Relationships between second language learning strategies and language proficiency in the context of learner autonomy and self- Regulation. Revista Canaria De Estudios Ingleses, 38, 109-126.

Oxford, R. L. (2001). Language learning styles and strategies. In M. Celce-Murcia (Ed.), Teaching English as a Second or Foreign Language (3rd ed.), (pp. 359-366). Boston: Heinle ELT.

Oxford, R. L. (2003). Language learning styles and strategies: An overview. Unknown. [Available online at: http://web.ntpu.edu.tw/ language/workshop/read2.pdf, Retrieved on May 19, 2015.]

Özmen, D. (2012). Language learning strategy preferences of Turkish students. International Journal of Humanities and Social Sciences, 2(10), 156-161.

Pashler, H., McDaniel, M., Rohrer, D., \& Bjork, R. (2008). Learning styles concepts and evidence. Psychological Science in the Public Interest, 9(3), 105-119. http://doi.org/10.1111/j.1539-6053.2009.01038.x

Pitler, H., Hubbell, E. R., \& Kuhn, M. (2012). Cooperative learning. In Using technology with classroom instruction that works, (2nd ed.), (pp. 154-169). Alexandria, VA: Association for Supervision \& Curriculum Development.

Raimes, A. (2000). Out of the woods: Emerging traditions in the teaching of writing. In D. R. H. Byrd, N. Bailey, \& M. R. Gitterman (Eds.), Landmarks of American Language and Linguistics, (pp. 152-164) Washington, DC: USA: Office of English Language Programs.

Reid, J. M. (1987). The learning style preferences of ESL students. TESOL Quarterly, 21(1), 87-111. http://doi.org/10.2307/3586356

Rose, H. (2012). Language learning strategy research: Where do we go from here? SiSAL Journal. [Available online at: http://sisaljournal.org/archives/jun12/rose/, Retrieved on May 19, 2015.]

Savignon, S. J. (2000). Communicative language teaching: State of the art. In D. R. H. Byrd, N. Bailey, \& M. R. Gitterman (Eds.), Landmarks of American Language and Linguistics, (pp. 74-83). Washington, DC: USA: Office of English Language Programs.

Savignon, S. J. (2001). Communicative language teaching for the twenty-first century. In M. Celce-Murcia (Ed.), Teaching English as a second or foreign language (3rd ed.), (pp. 13-28). Boston: Heinle ELT.

Savignon, S. J. (2007). Beyond communicative language teaching: What's ahead? Journal of Pragmatics, 39(1), 207-220. http://doi.org/10.1016/j.pragma.2006.09.004

Selçuk, H., (2016). A qualitative exploration of student perceptions of peer collaboration through the medium of online short story writing among Turkish public high school EFL learners in a social media environment. (Unpublished doctoral thesis). King's College London, London, UK.

Vardi, M. Y. (2012). Will MOOCs destroy academia? Communications of the ACM, 55(11), 55.http://doi.org/10.1145/2366316.2366317 
Yadollahi, H., \& Rahimi, A. (2015). The effects of different task types on learners' performance in collaborative virtual learning environment. Procedia - Social and Behavioral Sciences, 192 (Supplement C), 526-533. https://doi.org/10.1016/j.sbspro.2015.06.083

Yancey, K. B. (1999). Looking back as we look forward: historicizing writing assessment. College Composition and Communication, 50(3), 483-503.http://doi.org/10.2307/358862

\section{Appendix A.}

Table - 1: The List of the Participants with Different LLS and Language Knowledge

\begin{tabular}{|c|c|c|c|c|c|c|c|c|}
\hline D & $\mathrm{BC}$ & $\mathrm{BD}$ & $\mathrm{BE}$ & $\mathrm{BF}$ & BG & $\mathrm{BH}$ & $\mathrm{BI}$ & BJ \\
\hline $\begin{array}{l}\text { Participant } \\
\text { Num. }\end{array}$ & $\begin{array}{c}\text { PART A } \\
\text { Memory } \\
\text { strategies } \\
\text { MEM S }\end{array}$ & $\begin{array}{c}\text { PART B } \\
\text { Cognitive Strategie: } \\
\text { COG S }\end{array}$ & $\begin{array}{c}\text { PART C } \\
\text { Compensatory } \\
\text { Strategies } \\
\text { COM S }\end{array}$ & \begin{tabular}{|c} 
PART D \\
Meta-cognitive \\
Strategies \\
MET S
\end{tabular} & $\begin{array}{c}\text { PART E } \\
\text { Affective } \\
\text { Strategies } \\
\text { AS }\end{array}$ & $\begin{array}{c}\text { PART F } \\
\text { Social } \\
\text { Strategies } \\
\text { SS }\end{array}$ & Classification & $\begin{array}{l}\text { Level of English } \\
\text { Knowledge }\end{array}$ \\
\hline P1 & 2.9 & 2.9 & 3.0 & 2.9 & 3.5 & 3.3 & AS & 20 (A2) \\
\hline P2 & 3.4 & 2.8 & 2.7 & 2.6 & 2.0 & 3.3 & MEM S & 12 (A1) \\
\hline P3 & 2.4 & 2.5 & 2.8 & 2.8 & 3.5 & 2.5 & AS & 10 (A2) \\
\hline P4 & 4.3 & 3.6 & 3.3 & 3.2 & 2.8 & 4.3 & $\operatorname{cog} S$ & 18 (A2) \\
\hline P5 & 2.0 & 2.3 & 2.2 & 2.2 & 3.8 & 2.3 & AS & 19 (A2) \\
\hline P6 & 2.3 & 2.6 & 2.8 & 2.6 & 2.5 & 3.0 & SS & 14 (A1) \\
\hline P7 & 2.2 & 2.2 & 2.7 & 2.6 & 2.5 & 2.3 & coms & 17 (A2) \\
\hline P8 & 2.9 & 1.5 & 2.5 & 2.9 & 3.0 & 4.7 & SS & 11 (A1) \\
\hline P9 & 4.4 & 4.0 & 3.2 & 2.8 & 2.8 & 2.3 & MEM S & 15 (A1) \\
\hline P10 & 4.1 & 4.2 & 4.0 & 4.3 & 2.8 & 3.2 & MET S & 15 (A1) \\
\hline P11 & 2.7 & 2.4 & 2.0 & 2.1 & 2.5 & 2.8 & SS & 12 (A1) \\
\hline P12 & 1.9 & 1.8 & 1.7 & 1.2 & 1.7 & 2.5 & SS & 17 (A2) \\
\hline P13 & 3.1 & 2.8 & 2.7 & 2.4 & 2.5 & 2.3 & MEM S & 11 (A1) \\
\hline P14 & 1.9 & 2.5 & 1.7 & 1.6 & 1.2 & 3.0 & SS & 11 (A1) \\
\hline P15 & 2.0 & 1.9 & 2.2 & 2.2 & 1.8 & 3.2 & ss & 14 (A1) \\
\hline P16 & 2.4 & 1.4 & 1.7 & 1.3 & 1.3 & 2.0 & MEM S & 14 (A1) \\
\hline P17 & 2.4 & 2.1 & 2.7 & 1.7 & 1.2 & 1.8 & com s & 14 (A1) \\
\hline P18 & 2.6 & 2.6 & 2.3 & 3.0 & 2.8 & 3.0 & MET S / SS & 11 (A1) \\
\hline P19 & 2.4 & 2.8 & 4.2 & 3.0 & 3.3 & 4.0 & com S & 11 (A1) \\
\hline $\mathrm{P} 20$ & 2.9 & 3.2 & 2.7 & 2.9 & 2.8 & 3.3 & SS & 10 (A1) \\
\hline P21 & 3.4 & 3.9 & 3.8 & 3.7 & 3.3 & 3.5 & $\operatorname{cog} S$ & 15 (A1) \\
\hline \multirow[t]{10}{*}{ P22 } & 3.0 & 3.1 & 3.8 & 3.6 & 3.3 & 3.3 & COM S & 17 (A2) \\
\hline & 3.0 & 3.0 & 3.1 & 3.0 & 3.6 & 3.5 & & \\
\hline & MEM S & COGS & cOM S & METS & AS & ss & & \\
\hline & & & & & & & & \\
\hline & & & & Scoring for SILL & & & & \\
\hline & & & High & $\begin{array}{l}\text { Always or } \\
\text { almost always } \\
\text { Used. }\end{array}$ & 4.5 to 5.0 & & & \\
\hline & & & & Usually used. & 3.5 to 4.4 & & & \\
\hline & & & Medium & $\begin{array}{l}\text { Sometimes } \\
\text { Used. }\end{array}$ & 2.5 to 3.4 & & & \\
\hline & & & & $\begin{array}{l}\text { Generally not } \\
\text { Used. }\end{array}$ & 1.5 to 2.4 & & & \\
\hline & & & Low & \begin{tabular}{|l} 
Never or almost \\
Never used.
\end{tabular} & 1.0 to 1.4 & & & \\
\hline
\end{tabular}

\section{Appendix B.}

\section{Screen-shot - 1: Warm - up Questions}

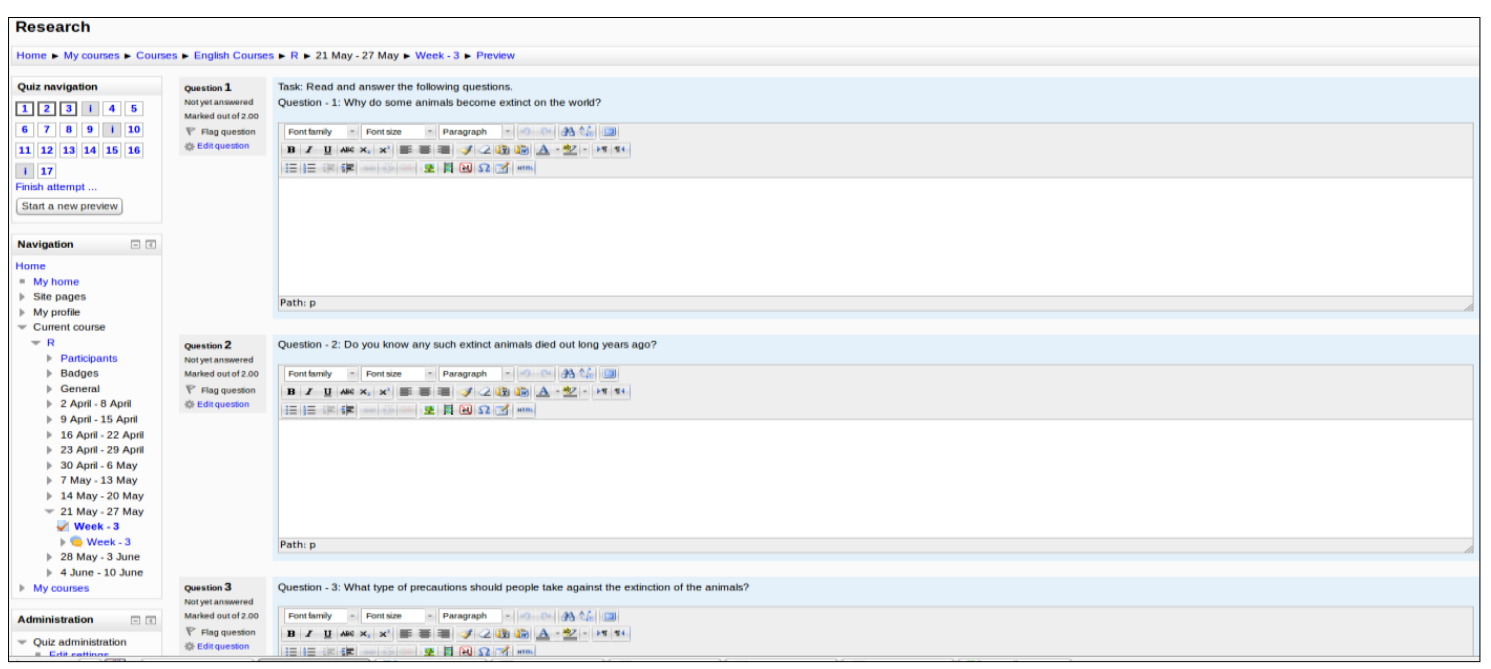




\section{Screen-shot - 2: Pre-Reading Activity}

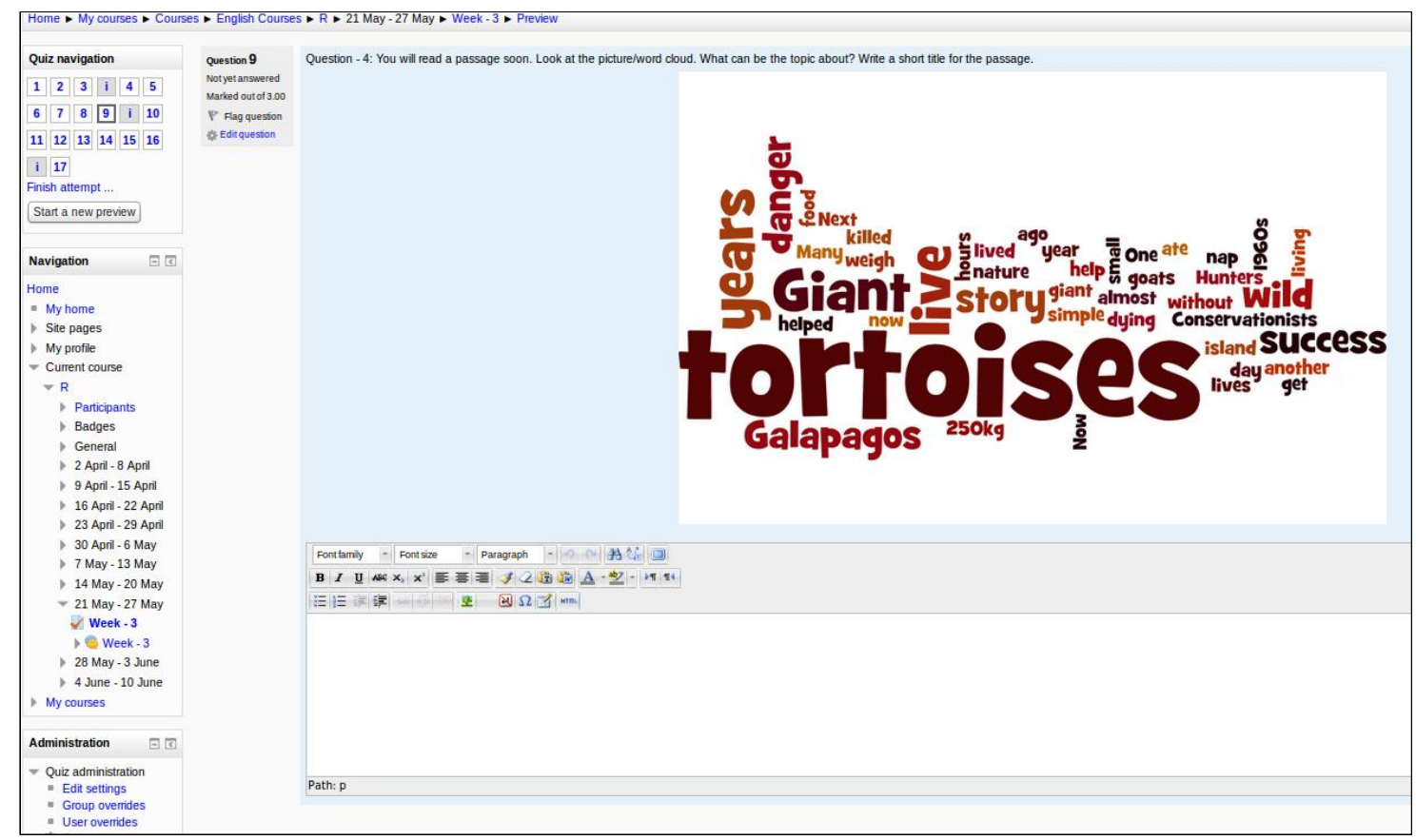

\section{Screen-shot - 3: Reading Activity}

Week -3 > Preview

Information

P Flag question

क Edit question

\section{Galapagos tortoises out of danger}

Giant Galapagos tortoises were in danger. There were only 15 of them in the 1960s. They were dying because wild goats ate their food. Conservationists

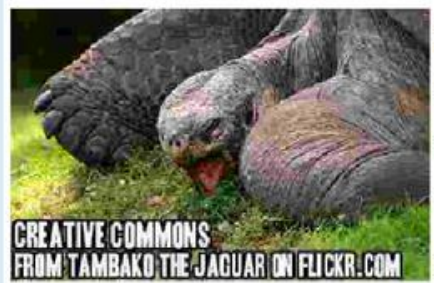
helped them. Now, there are over 1,000 living in the wild. It is a success story for nature. Many tortoises can now live without our help.

There were 250,000 giant tortoises 500 years ago. Hunters almost killed them all. Giant tortoises can weigh $250 \mathrm{~kg}$ and live for 100 years. One lived for 170 years. Giant tortoises live very simple lives. They can nap for 16 hours a day. Next year, a small island will get 200 tortoises. This could be another success story.

Adapted from: http://www.breakingnewsenglish.com

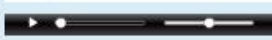




\section{Screen-shot - 4: Listening Activity}

\begin{tabular}{|c|c|c|}
\hline Research & & \\
\hline Home $\boldsymbol{\sim}$ My courses $\boldsymbol{V}$ Cour & - English Cours & $-R=21$ May -27 May - Week $-3=$ Preview \\
\hline Quiz navigation & Information & Listen to the following record and choose the correct answers. \\
\hline \begin{tabular}{|l|l|l|l|l|}
1 & 2 & 3 & 1 & 4 \\
\end{tabular} & $\begin{array}{l}\text { Plag question } \\
\text { to Edin question }\end{array}$ & $\Rightarrow+\infty=$ \\
\hline \begin{tabular}{|l|l|l|l|l|l|}
6 & 7 & 8 & & \\
\end{tabular} & & \\
\hline \begin{tabular}{|l|l|l|l|l|l|l}
11 & 12 & 13 & 14 & 15 & 16 \\
\end{tabular} & Question 4 & Question - 1: Giant Galapagos tortoises were .............. . \\
\hline \begin{tabular}{|l|l}
$\mathbf{i}$ & 17 \\
Finish attempt $\ldots . .$. & \\
\end{tabular} & $\begin{array}{l}\text { Not yet answered } \\
\text { Marked out of } 1.00\end{array}$ & Select one: \\
\hline $\begin{array}{l}\text { Finish attempt ... } \\
\text { Start a new preview }\end{array}$ & $P$ Flag question & a. c) on danger \\
\hline Ltart a new prevew & Edin question & b. b) under danger \\
\hline Navigation $\quad \square \square$ & & c. a) in danger \\
\hline Home & & \\
\hline $\begin{array}{l}\text { My home } \\
\text { S Ste pages } \\
\text { My profile }\end{array}$ & $\begin{array}{l}\text { Question } 5 \\
\text { Not yet answered } \\
\text { Marked out of } 1.00\end{array}$ & $\begin{array}{l}\text { Question - 2: They were dying because wild goats ............... their food. } \\
\text { Select one: }\end{array}$ \\
\hline Current course & P Flag question & a. a) eat \\
\hline Participants & & b. b) ate \\
\hline $\begin{array}{l}\text { Badges } \\
\text { General } \\
\text { \& } 2 \text { April - } 8 \text { April }\end{array}$ & & c.c) eight \\
\hline $\begin{array}{l}\text { 9 April - } 15 \text { April } \\
16 \text { Appril - } 22 \text { April } \\
\text { (23 April - } 29 \text { April }\end{array}$ & $\begin{array}{l}\text { Question } 6 \\
\text { Notyet answered } \\
\text { Marked out of } 1.00\end{array}$ & $\begin{array}{l}\text { Question - 3: It is a .................... story for nature. } \\
\text { Select one: }\end{array}$ \\
\hline 30 April - 6 May & $P$ Flag queston & a. c) sample \\
\hline $\begin{array}{l}7 \text { May - } 13 \text { May } \\
14 \text { May-20 May }\end{array}$ & \% Edit question & b. a) success \\
\hline $\begin{array}{l}21 \text { May }-27 \text { May } \\
\text { Week-3 } \\
\$ 0 \text { Week -3 }\end{array}$ & & c. b) suggest \\
\hline $\begin{array}{l} \\
28 \text { May - } 3 \text { June } \\
\text { 4 June }-10 \text { June } \\
\text { My courses }\end{array}$ & $\begin{array}{l}\text { Question } 7 \\
\text { Notyet answered } \\
\text { Marked out of } 1.00\end{array}$ & $\begin{array}{l}\text { Question - 4: There were .................. giant tortoises } 500 \text { years ago. } \\
\text { Select one: }\end{array}$ \\
\hline Administration & $\begin{array}{l}P \text { Flag question } \\
\text { o. Edit question }\end{array}$ & a. c) 250,000 \\
\hline Quiz administration & & b. b) 2500 \\
\hline & & c. a) 200,000 \\
\hline
\end{tabular}

\section{Screen-shot - 5: EtherPad Links for Groups}

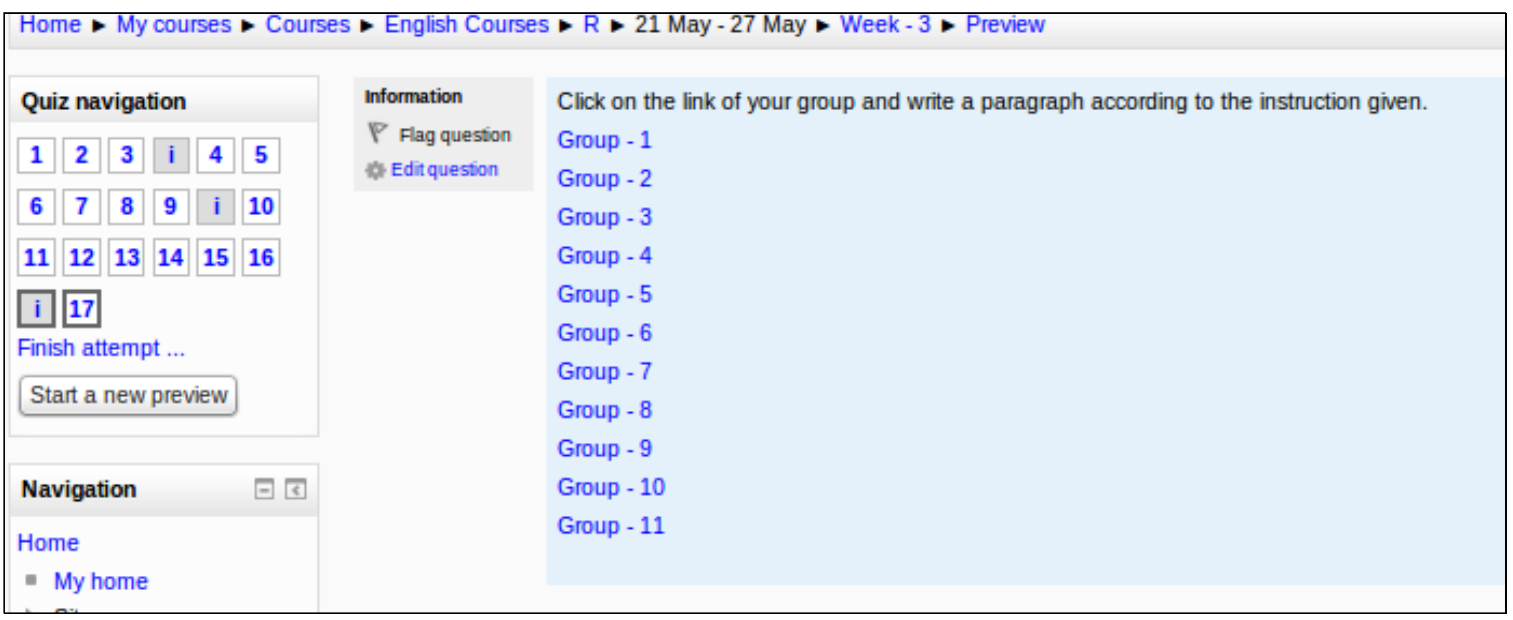




\section{Screen-shot - 6: SOCW Task, Corrective and Suggestive Feedback}

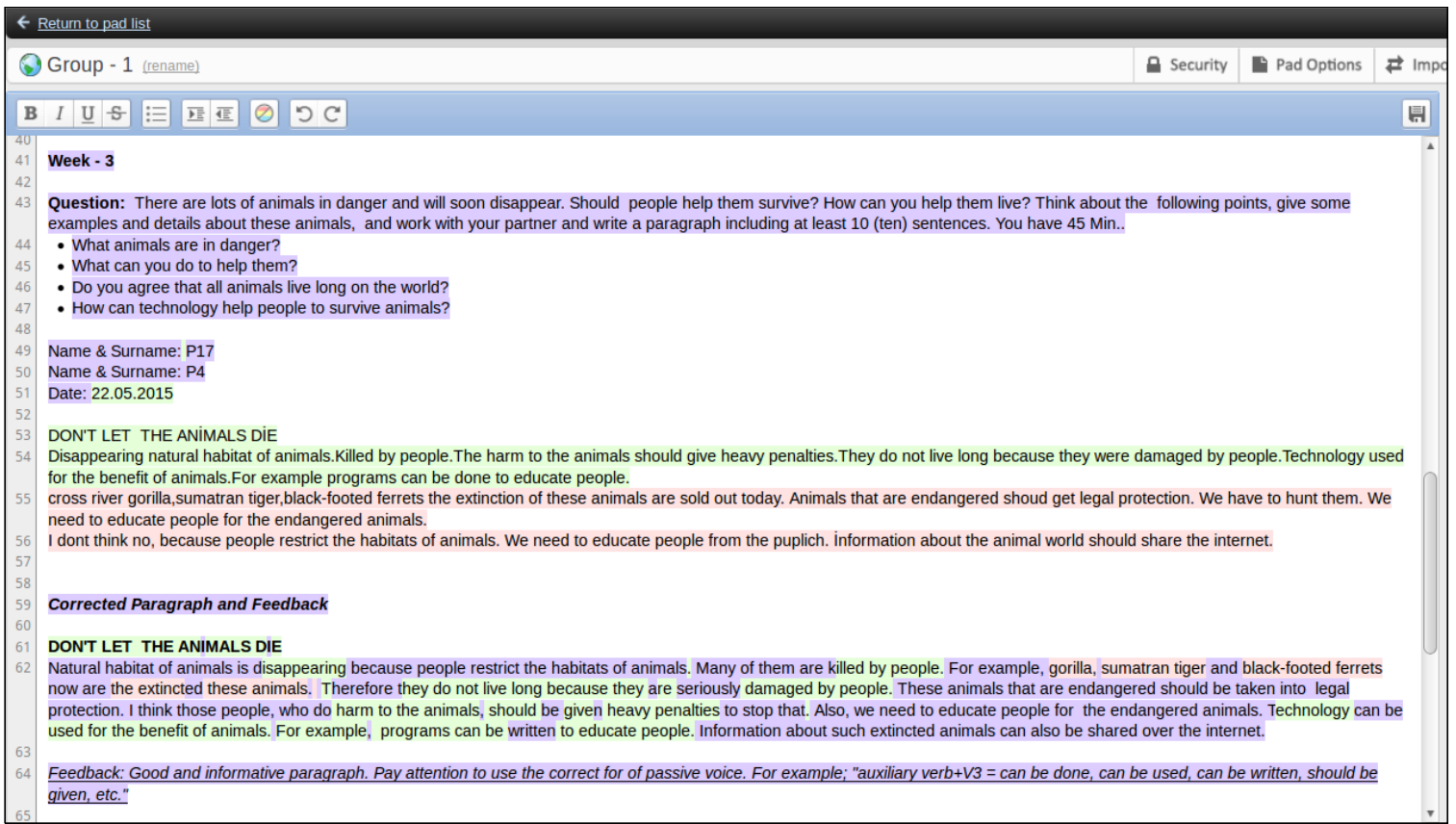

\section{Screen-shot - 7: Sample of Separately Written Paragraph}

Week - 3

Question: There are lots of animals in danger and will soon disappear. Should people help them survive? How can you help them live? Think about the following points, give some examples and details about these animals, and work with your partner and write a paragraph including at least 10 (ten) sentences. You have $45 \mathrm{Min}$. .

- What animals are in danger?

- What can you do to help them?

- Do you agree that all animals live long on the world?

- How can technology help people to survive animals?

Name \& Surname: P17

Name \& Surname: P4

Date: 22.05 .2015

\section{DON'T LET THE ANIMALS DIE}

Disappearing natural habitat of animals.Killed by people.The harm to the animals should give heavy penalties. They do not live long because they were damaged by people.Technology used for the benefit of animals.For example programs can be done to educate people.

cross river gorilla,sumatran tiger,black-footed ferrets the extinction of these animals are sold out today. Animals that are endangered shoud get legal protection. We have to hunt them. We need to educate people for the endangered animals. I dont think no, because people restrict the habitats of animals. We need to educate people from the puplich. Information about the animal world should share the internet. 


\title{
Screen-shot - 8: Sample of Collaboratively Written Paragraph
}

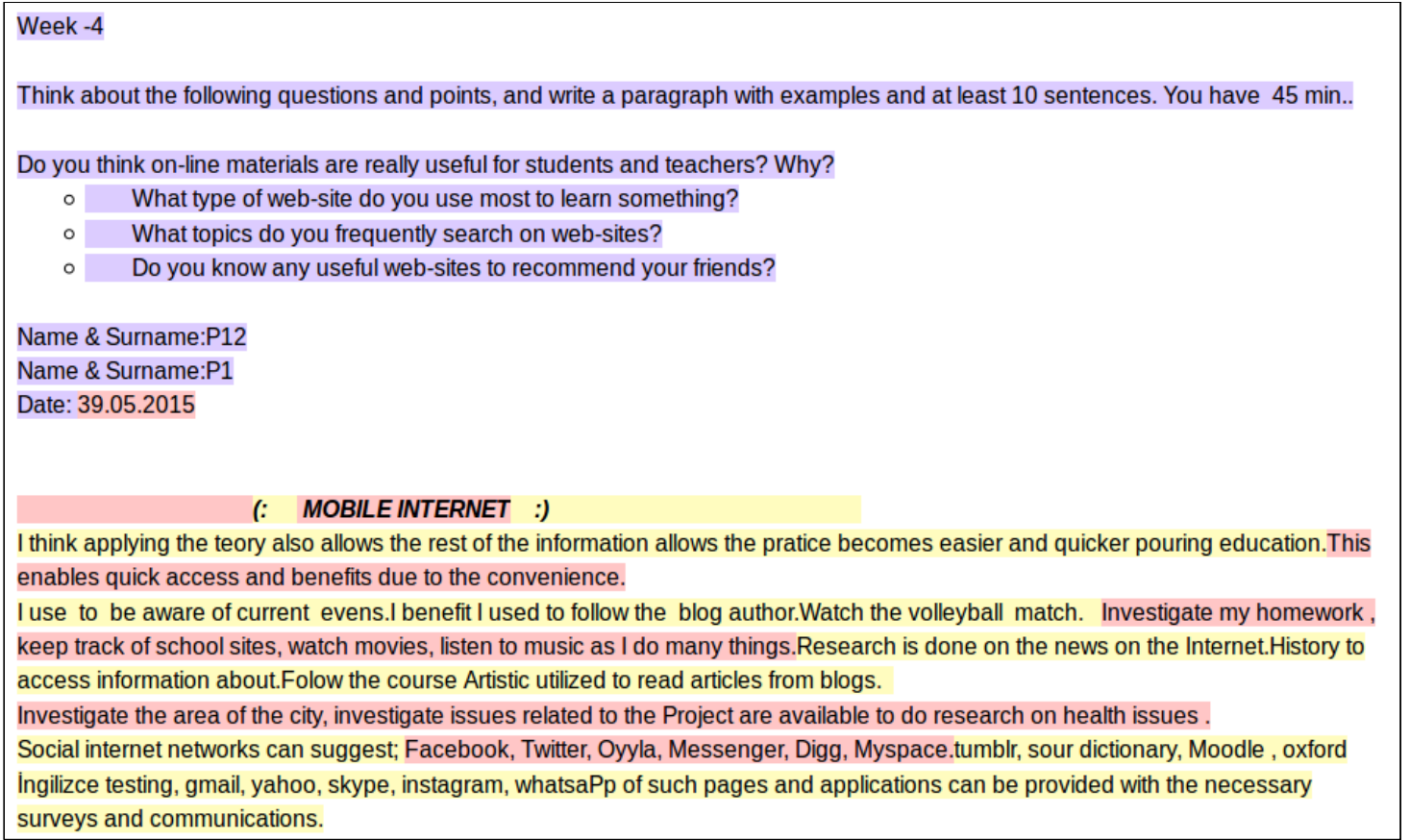

\section{Appendix C.}

\author{
Graph - 1
}

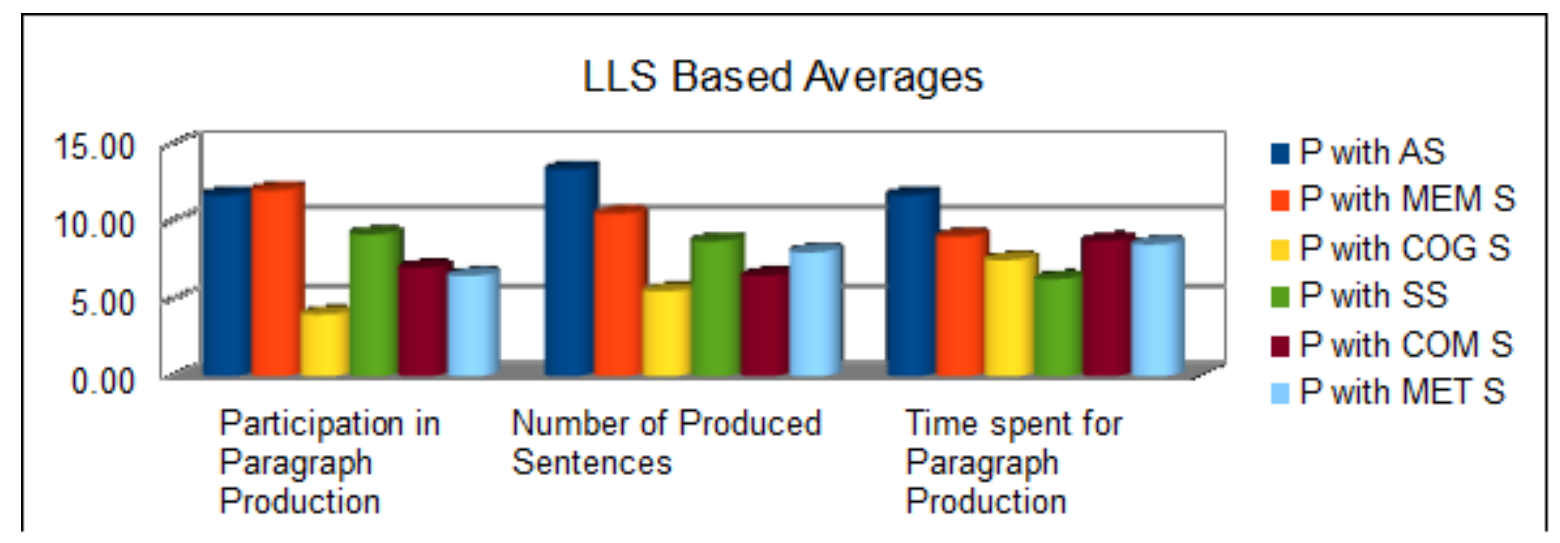

Graph-2 


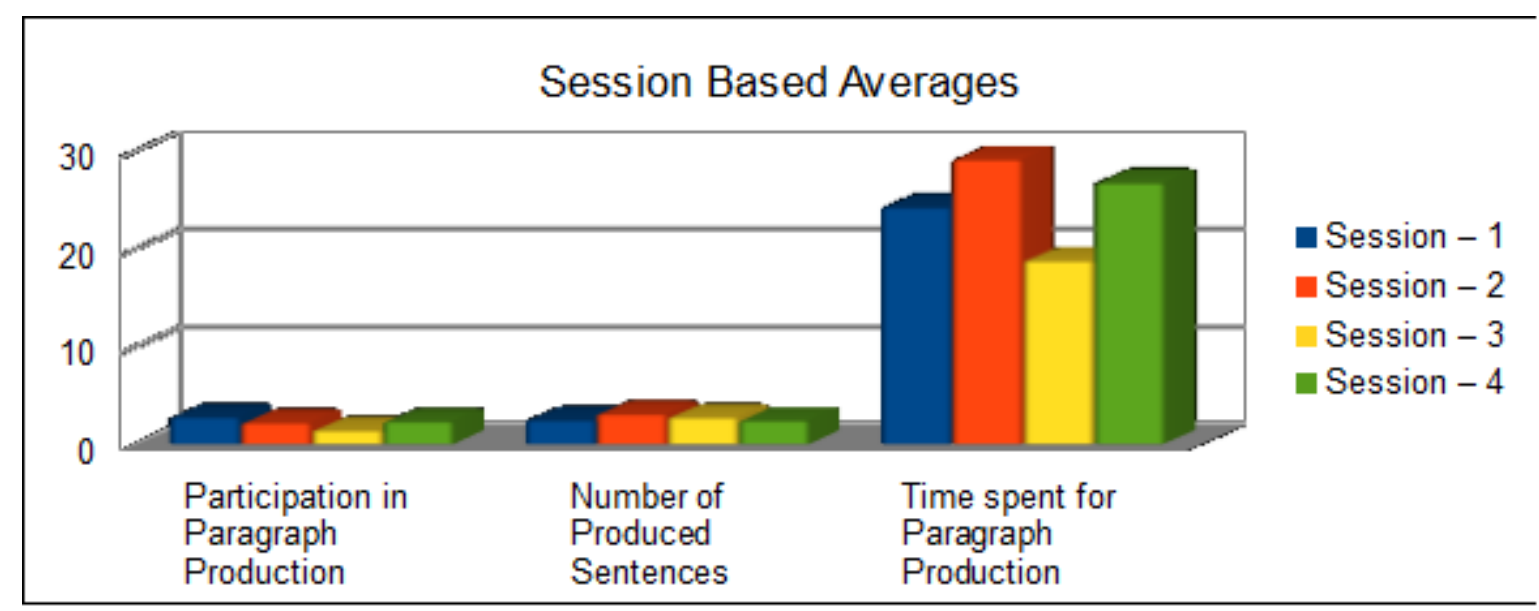

Graph -3

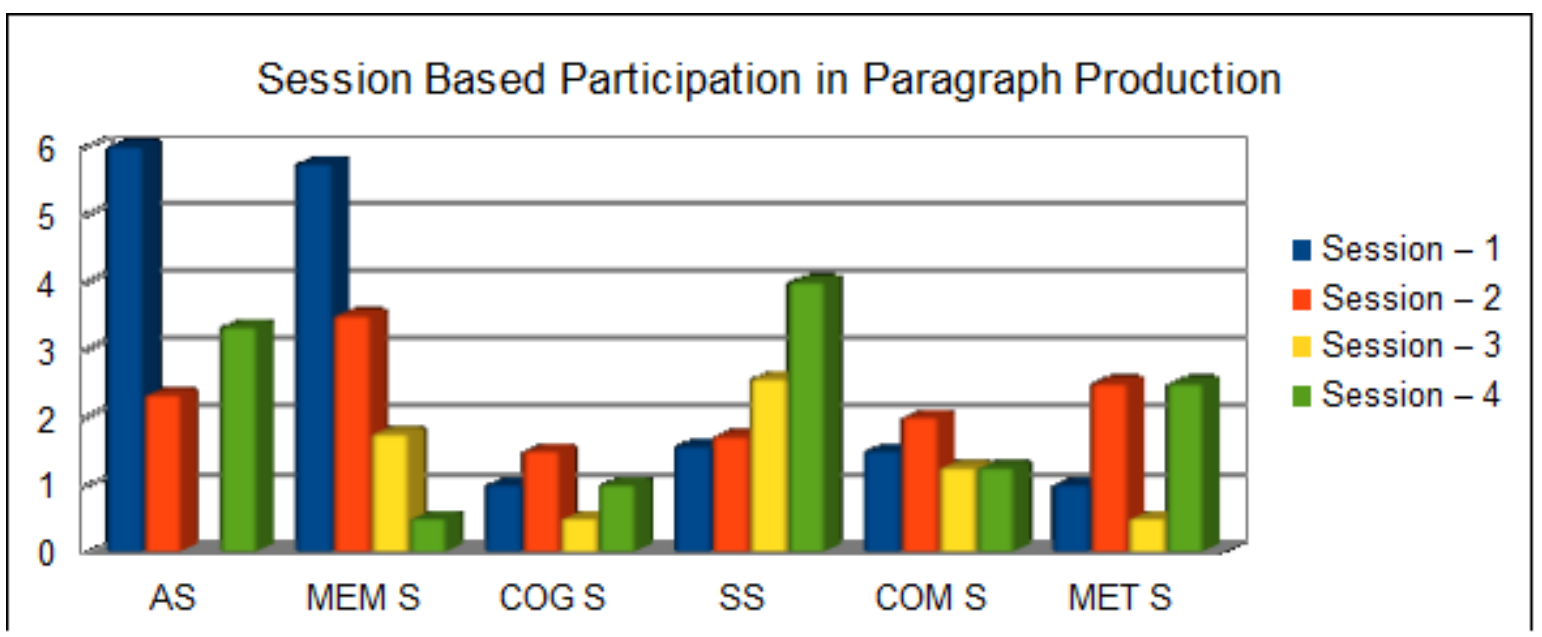

Graph -4

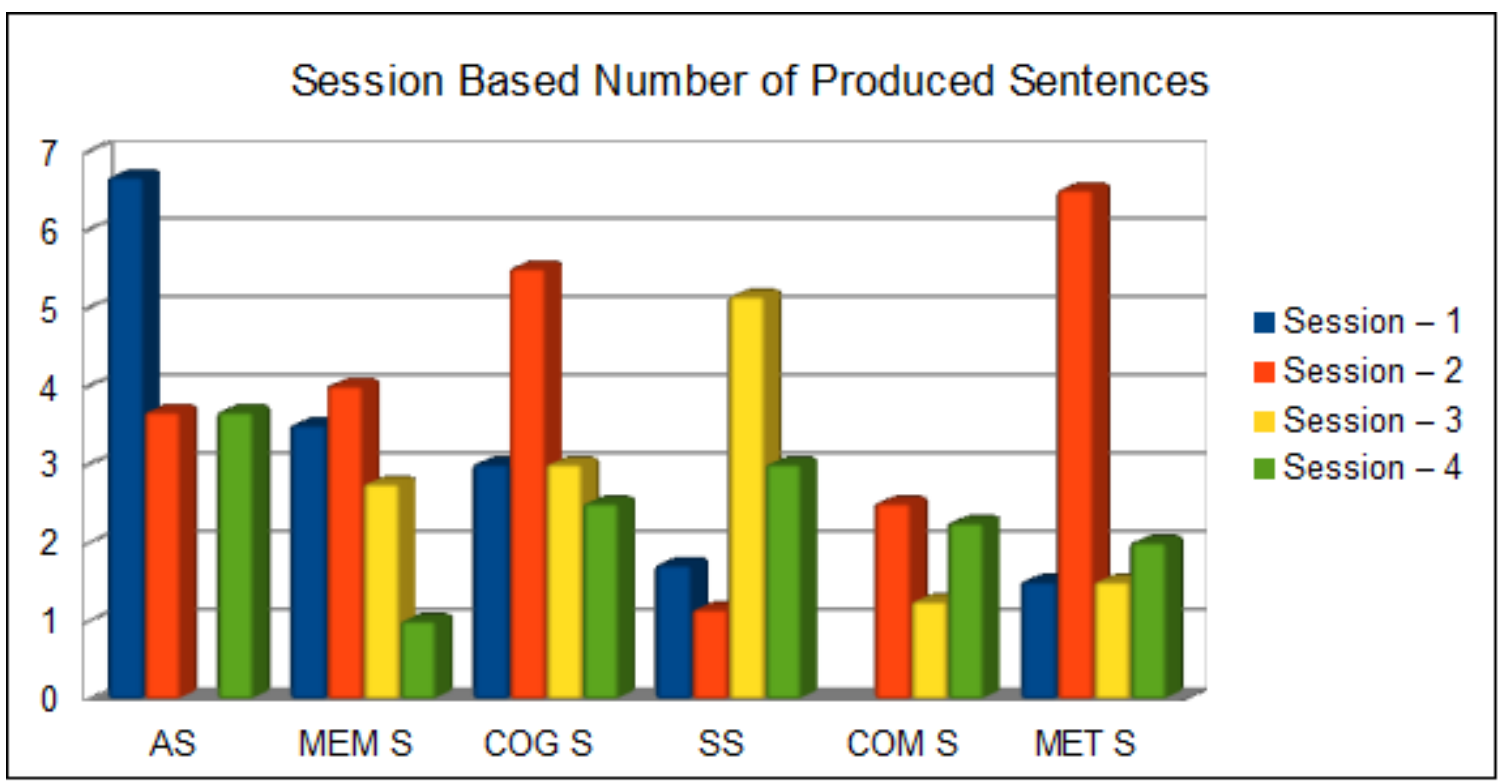


Graph - 5

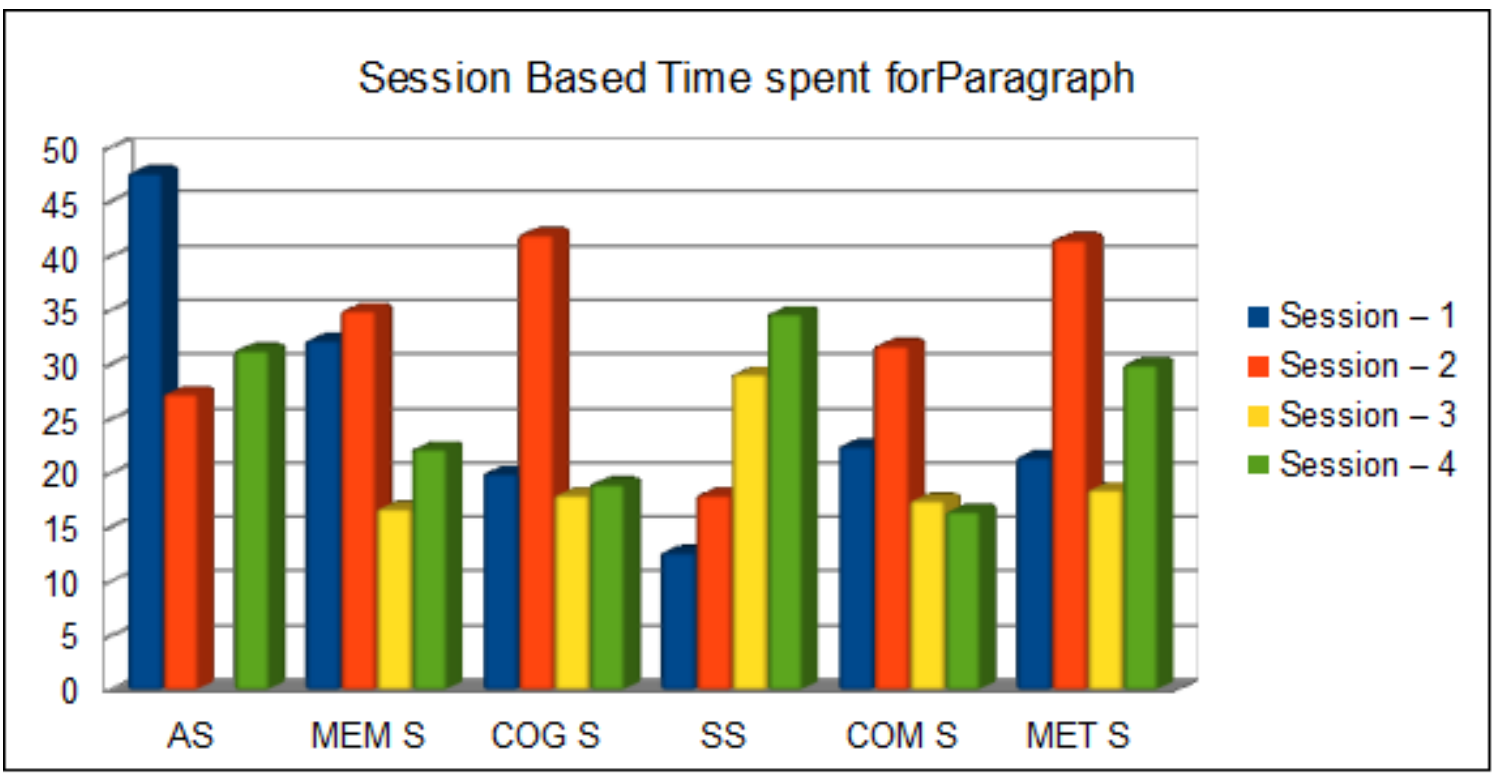

\section{Copyrights}

Copyright for this article is retained by the author(s), with first publication rights granted to the Journal.

This is an open-access article distributed under the terms and conditions of the Creative Commons Attribution license (CC BY-NC-ND) (http://creativecommons.org/licenses/by-nc-nd/4.0/). 